would certainly lead any one acquainted with the subject to believe that he had acted on it. The only clues afforded by the work which indicate that the Owenian system was not adopted in its entirety, now pointed out by Mr. Lydekker as existing at pp. 152, 174, would certainly escape the notice of any one who had not actually spelled through the work, as I feel sure whoever will take the trouble to refer to will agree with me.

There is no evidence whatever to support Mr. Lydekker's assumption that the two anterior premolars in Vespertilio and the anterior premolar in Rhinolophus correspond, respectively, to $p m s, 2$ and 3 and to $p .3$ of the typical series. On the contrary, the small size of the second premolar in Vespcrtilio points to reduction by loss from the middle of the series, as we find in the greater number of species of the closely-allied order, Insectivora, and, as we know, takes place in the mandible of several species of Chiroptera.

With reference to the wish expressed in the review that, instead of writing a mere catalogue of the fossil mammals in the British Museum, Mr. Lydekker had undertaken one of all the known species, and his objection, while regretting that the intended friendly estimate of his capability for such a work has been so hostilely received, 1 maintain that such should have been undertaken; but Mr. Lydekker's remarks show how necessary it is, and that the objection that new genera and species are being made almost daily (it is probable that they will continue to be be made to the end of time) might be applied with equal force on behalf of the birds by Mr. Sharpe, who nevertheless continues his excellent catalogue. It is only by the publication of such a work that we can hope to limit the mantifacture of "empty names," such as Mr. Lydekker objects to, and to reduce to order the vast amount of scattered information and contesting opinions which encumber the study of the subject. THE REVIEWER

\section{THE ORCHID EXHIBITION}

THE Exhibition held in the Conservatory at South Kensington on the 12 th and $13^{\text {th }}$ inst. in connection with the Orchid Conference of the Royal Horticultural Society, must have furnished to the least observant visitor some explanation of the fascination exercised by orchids over their cultivators. The beauty, the variety, the strangeness of the flowers of the Orchideæ attract and interest the least enthusiastic even of the lovers of nature. But the variation in flower, compatible with botanical inclusion in one family, is not more marked than is the difference in mode of flowering and of growth. Could there be in one natural order a stronger contrast than between the mode of growth and the gorgeous flowers of the genus Cattleya-essentially "flaunting flowers"-and those of the genus Masdevallia, where the conspicuous part of the flower consists of the three sepals, drawn out in many species into thread-like tails many inches long, and ranging in colour through every shade of orange, scarlet, and purple, down to an almost inky black!

While a larger array of specimen plants has often been seen than was shown at the Conference, there has never been gathered together in any country so varied and interesting a collection, nor one containing so many rare and curious plants. Great as was the interest for the cultivator, it was no less great for the botanist. Mr. Ridley, of the Natural History Museum, who, in conjunction with $\mathrm{Mr}$. Burbidge, of the Dublin Botanic Gardens, has undertaken to draw up a report on the Conference Exhibition, found that sixty-one genera of orchids were represented. For the first time in the history of flower-shows there was a numerous collection of hybrid orchids, raised by artificial fertilisation, in flower. For the first time was there a large collection of orchids in fruit. The progress of hybridisation, greatly due to the energy and skill of Messrs. Veitch and Sons and their intelligent foremen, Mr. Dominy and Mr. Seden, has already been fertile in valuable results for the cultivator. An excellent little book lately published, gives a list of eighty-nine hybrids already in cultivation, I "Orchids: a Review of their Structure and History," Illustrated. By
Lewis Castle. (Journal of Horticulture Office, $17 \mathrm{I}$, Fleet Street, E.C.) distributed among twelve genera; but thirty-seven of them belonging to the genus Cypripedium. Those who are privileged to enter the penetralia at Chelsea know that there are there and elsewhere great numbers and varieties of hybrids, which are slowly surmounting the dangers and delicacy of infancy and childhood.

But the labours of the hybridiser promise to be of great value to the botanist. Mr. Harry Veitch, in his very suggestive and interesting paper on the "Hybridisation of Orchids," read at the Conference, says: "How will these bigeneric crosses affect the stability of the genera as at present circumscribed?" It is well established already that the genera Lœlia and Cattleya cross freely with one another, and $\mathrm{Mr}$. Veitch refers in his paper to two other bigeneric hybrids, which have already flowered, and to others which have been raised, but have not yet flowered.

Unfortunately it must be a long time before orchid cultivators generally can enjoy the results of hybridisation. $\mathrm{Mr}$. Veitch gives the time the hybridist must wait to see the result of his labours, as follows:-

\begin{tabular}{|c|c|c|c|c|c|}
\hline Genus. & & & & & $\begin{array}{l}\text { Time from Germinatio } \\
\text { to Flowering }\end{array}$ \\
\hline Dendrobium & $\ldots$ & $\cdots$ & .. & $\ldots$ & 3 to 4 years. \\
\hline Phaius ... & $\ldots$ & $\ldots$ & $\ldots$ & $\cdots$ & About the same. \\
\hline Calanthe & $\ldots$ & $\cdots$ & $\ldots$ & $\cdots$ & \\
\hline Masdevallia & $\ldots$ & $\ldots$ & $\ldots$ & $\cdots$ & 4 to 5 years. \\
\hline Chysis ... & $\cdots$ & $\ldots$ & $\ldots$ & $\cdots$ & \\
\hline Zygopetalum & $\ldots$ & $\ldots$ & $\ldots$ & $\ldots$ & 5 to 9 years. \\
\hline Lycaste ... & $\ldots$ & $\ldots$ & $\ldots$ & $\cdots$ & 7 to 8 years. \\
\hline Lœlia ... & $\cdots$ & $\cdots$ & $\cdots$ & $\cdots$ & Io to 12 years. \\
\hline Cattleya & ... & $\ldots$ & $\ldots$ & $\cdots$ & 25 gentant \\
\hline
\end{tabular}

With the exception of the genera Dendrobium and Cypripedium, it is a long time before sufficient plants of a hybrid can be obtained for distribution, even under the most skilful cultivation. For this reason many of the more beautiful hybrids will probably remain scarce and valuable for years. The high prices paid by collectors for orchids in some cases have been a source of merriment to the uninitiated. Speaking generally, orchids were never so cheap or so plentiful. But if a collector must have a hybrid which has been raised by skilful hands and nursed into vigour by years of patient care-or, on the other hand, must have a beautiful natural variety which has been picked out of millions of plants-if he must have them, he must pay for them.

The Royal Horticultural Society is to be congratulated both on the botanical and the horticultural results of the late Conference. The Conference was a new idea, a new departure. It has demonstrated the great, widespread, and, better still, the intelligent interest taken in a singular and beautiful natural order, and the skill brought to bear on its cultivation.

The short scientific contributions of Prof. Reichenbach, whose absence was universally regretted; the paper on "Hybridisation," by Mr. Veitch, and the brief discussion which ensued, were listened to by a large and appreciative conference. The paper on "Cultivation," by Mr. O'Brien, was also interesting and valuable. The very difficult question of nomenclature, which is in so confused and unsatisfactory a state as to ill brook delay, was postponed. It could not be discussed with advantage at the tail of a long meeting, and will be referred, it is to be hoped, to a a scientific committee selected from botanists in and out of the Royal Horticultural Society.

T. L.

\section{WHEAT-PRODUCTION IN INDIA ${ }^{1}$}

NDIA has recently exhibited her extraordinary powers as a wheat-producing area of vast extent. Up to the year 1877 the British wheat-grower looked upon the exhaustless prairies of the far West as his most formid-

$t$ The Wheat-Production and Trade of India. Calcutta. Being a collection of correspondenee in continuation of papers published in 1879 . 
able rival in the matter of wheat-growing. A short seven years has greatly altered his feelings in this respect, and we are probably right in considering that the far East is destined to do its part in forcing down the price of wheat to as great a degree as the land of the setting sun. The brochure before us is a thoroughly dry statement of facts composed of numbered despatches, letters, and tables, all bearing upon the capabilities of India as a wheat-producing country. The reader will not, however, obtain information as to extent or area, except in a more or less incidental manner. The principal matters dealt with are (I) the quality and comparative values of the various wheats grown; (2) the modes of cultivation pursued; (3) the nature of the soils on which wheat is grown; (4) the average yield per acre; (5) the effects of continuous wheat-growing in diminishing yield; and also other matters relating to the details of wheat-cultivation in India.

With regard to the quality of Indian wheats there is no room for doubt. The conclusions arrived at are based upon actual weight per bushel, value upon the Corn Exchange at Mark Lane, and an elaborate report upon milling and bread-making results furnished by Messrs. McDougall Brothers of Io, Mark Lane, London. From whichever of the above points of view we test the quality of the Indian wheat, the result is equally satisfactory, and the more so when we find that from year to year the samples and bulk continue to improve. Messrs. McDougall Brothers go so far as to sum up their experience by saying, "glancing at all the facts, it is evident that these wheats afford a larger margin of profit both to the miller and baker than any other."

The modes of cultivation adopted are of great interest. They usually exhibit vast pains, and are in this respect superior to the system of wheat-cultivation employed at home. Such elaborate cultivation would indeed astonish an English farmer accustomed to plough his lea land or turnip land once for wheat. The comparison is less fair if we take into consideration the fact that one thorough English ploughing may be worth half-a-dozen of those "ticklings" of the soil which, under Indian skies, are sufficient to make it "laugh." Under the head of Systems of Cultivation we read:- "Ploughed in July, and again six or seven times until October. Watered in November. Again ploughed twice, rolled, ploughed again, and the seed sown through a tube attached to a plough-handle. After twenty-five or thirty days, again watered; and this is repeated until the plants appear fortnightly where irrigation is by lift, and every twentyfive days where it is by flow. In February, when the ears have appeared, water is given weekly until the ears begin to mature." In Armritsar ;-"Six months before sowing, the land is ploughed five to ten times. After sowing, the crops are watered not less than six or more than nine or or ten times." In Gujrat:- "Land is broken up and ploughed many times between May and September, manured and ploughed and levelled." The average produce per acre after this system of cultivation varies from seven to fourteen or even twenty maunds (nine to twentyseven bushels of $6 \mathrm{r} \mathrm{lbs}$.), and yet it is calculated that it is grown at from $8 s$. to I I $s$. per quarter! Wheat-growing appears to be carried on upon all sorts of soils. Upon stiff loams, sandy loams, hard clay, and "every kind of soil." In reply to the question, Has the productive power of the soil begun to fail? the answers are usually in the negative, or that it is not apparent. Still, as might be expected, better crops are grown upon manured and irrigated soils and upon those newly broken up from pasturage.

After reading the details of wheat-cultivation in India and compared its results with those obtained in England with a fifth part of the labour, we are inclined to wonder greatly that this remote field should be able to compete with us. Why do they plough five to ten times? How is it that in that sumny land, and after all this expenditure of labour and irrigation, twenty-seven bushels should be a maximum return, while in some cases seven bushels is all that is reaped? A painstaking farmer in England hopes for from thirty-two to forty bushels per acre after once ploughing and pressing his clover leys, and yet he cannot make both ends meet, nor yet compete with the Indian Ryot.

JOHN WRIGHTSON

\section{THE REPORTS OF THE UNITED STATES COMMISSION OF FISH AND FISHERIES FOR I88I $A N D$ 1882 2}

THE Report for I $88 \mathrm{I}$ was presented to the Senate and Congress of the United States on March I7, 1882; it is to be regretted that so long an interval was allowed to elapse before its publication. The volume is a large one, three inches in thickness, and containing nearly 1200 pages. Scarcely any of this large quantity of letterpress is without interest and value, and we here give an account of the work described in it.

The Commission began the second decade of its existence in $188 \mathrm{I}$, and the present report shows how greatly the organisation has extended itself, and what large results it has achieved in its first ten years. The central offices of the Commission are at Washington, and up to the year I88I were confined to the private residence of its public-spirited chief, Mr. Spencer Baird, who devoted the greater part of his house to the State service without remuneration. In I88I a building was erected next to the Commissioner's residence, at the public expense, to provide space for the increased administrative work. The stations where the varied operations of the Commission are carried on are scattered throughout the United States territory. These operations fall naturally under three heads : (r) Economical statistics and historical data concerning the fishing industries; (2) the applied science of regulating fish supply and distribution; (3) the pure science of marine zoology. The part of the work belonging to the first of these divisions is conducted partly at the central offices, partly at the seats of the industries in question. The two other fields of work are, of course, not always distinctly separate. Since I 878 buildings at Fort Wharf, Gloucester, Mass., had been occupied for hatching operations, but in $188 \mathrm{I}$ they passed into the possession of a private firm, since which time only reports on the fisheries and records of ocean and atmospheric temperatures have been obtained from Gloucester. The principal site of the purely scientific work during the summer season was Wood's Holl, Mass., where the Commission possessed a sea-side laboratory. Researches on the artificial propagation of oysters, \&c., were carried on at St. Jerome, Md., near the mouth of the Potomac. Cultivation of the land-locked or Schoodic salmon was practised on the Grand Lake Stream, near Calais, Me. The Penobscot or Atlantic salmon (Salmo salar) similarly received attention at Buckport, Me. Another station, where lake trout, brook trout, California trout, \&c., were hatched, was at Northville. The principai hatchery for the Californian salmon was on the McCloud River, a branch of the Sacramento. Shad eggs were hatched at Battery Island, Md., at North-East River, Md., near the mouth of the Susquehanna, at the Central Station, Armory Buildings, Washington, at Washington Navy Yard, on the Potomac river-barges, and at Avoca, N.C. Carp ponds were maintained at Monument Lot and at the Arsenal, Washington. The Commission acknowledges valuable assistance received from almost all departments of the Government, but especially from the Navy Office, which, in compliance with decrees of Congress, has detailed steamers fully manned and equipped, lent launches, and executed work and repairs at the navy yards. Steam 